\title{
Calcium fluxes in Hoplosternum littorale (tamoatá) exposed to different types of Amazonian waters
}

\author{
Bernardo Baldisserotto ${ }^{1}$, Carlos Eduardo Copatti², Levy Carvalho Gomes ${ }^{3}$, \\ Edsandra Campos Chagas ${ }^{4}$, Richard Philip Brinn ${ }^{5}$ and Rodrigo Roubach ${ }^{6}$
}

Fishes that live in the Amazonian environment may be exposed to several kinds of waters: "black waters", containing high dissolved organic carbon and acidic $\mathrm{pH}$, "white waters", with ten fold higher $\mathrm{Ca}^{2+}$ concentrations than black waters and neutral $\mathrm{pH}$, and "clear waters", with two fold higher $\mathrm{Ca}^{2+}$ concentrations than black waters and also neutral $\mathrm{pH}$. Therefore, the aim of the present study was to analyze $\mathrm{Ca}^{2+}$ fluxes in the facultative air-breather Hoplosternum littorale (tamoatá) exposed to different Amazonian waters. Fishes were acclimated in well water (similar to clear water) and later placed in individual chambers for $\mathrm{Ca}^{2+}$ fluxes measurements. After $4 \mathrm{~h}$, water from the chambers was replaced by a different type of water. Transfer of tamoatás to ion-poor black or acidic black water resulted in net $\mathrm{Ca}^{2+}$ loss only in the first $2 \mathrm{~h}$ of experiment. However, transfer from black or acidic black water to white water led to only net $\mathrm{Ca}^{2+}$ influxes. The results obtained allowed us to conclude that transfer of tamoatás to ion-poor waters (black and acidic black water) led to transient net $\mathrm{Ca}^{2+}$ loss, while the amount of $\mathrm{Ca}^{2+}$ in the ion-rich white water seems adequate to prevent $\mathrm{Ca}^{2+}$ loss after transfer. Therefore, transfer of tamoatás between these Amazonian waters does not seem to result in serious $\mathrm{Ca}^{2+}$ disturbance.

Os peixes que vivem na Amazônia são expostos a vários tipos de água: águas pretas, contendo grande quantidade de carbono orgânico dissolvido, águas brancas, com concentração de $\mathrm{Ca}^{2+}$ dez vezes maior que as águas pretas e pH neutro, e águas claras, com concentração de $\mathrm{Ca}^{2+}$ duas vezes maior que as águas pretas e $\mathrm{pH}$ também neutro. Dessa forma, o objetivo deste trabalho foi analisar o fluxo de $\mathrm{Ca}^{2+}$ no peixe de respiração aérea facultativa Hoplosternum littorale (tamoatá) exposto a diferentes tipos de águas amazônicas. Os peixes foram aclimatados em água de poço artesiano (semelhante à água clara) e depois colocados individualmente em câmaras para medir o fluxo de $\mathrm{Ca}^{2+}$. Após $4 \mathrm{~h}$, a água das câmaras foi trocada por um tipo diferente de água. A transferência do tamoatá das águas pobres em íons água preta e preta ácida ou da água branca, rica em íons, para as águas preta e preta ácida, pobres em íons, resulta em uma perda de $\mathrm{Ca}^{2+}$ apenas nas duas primeiras horas de experimento. Entretanto, a transferência da água preta e preta ácida, para a água branca resulta em um influxo de $\mathrm{Ca}^{2+}$. Os resultados obtidos nos permitem concluir que a transferência do tamoatá para as águas preta e preta ácida, pobres em íons, leva a uma temporária perda de $\mathrm{Ca}^{2+}$, e a quantidade de $\mathrm{Ca}^{2+}$ na água branca, rica em íons, é adequada para prevenir sua perda após a transferência. Sendo assim, a transferência do tamoatá entre as águas estudadas não resulta em sérios distúrbios no $\mathrm{Ca}^{2+}$.

Key words: Ion flux, Negro River, Amazon River, Acidic water.

${ }^{1}$ Departamento de Fisiologia e Farmacologia, Universidade Federal de Santa Maria - UFSM, 97105-900 Santa Maria, RS, Brazil. bbaldisserotto@hotmail.com

${ }^{2}$ Departamento de Ciências da Saúde, Universidade de Cruz Alta, Cruz Alta, RS, Brazil. carloseduardocopatti@yahoo.com.br

${ }^{3}$ Centro Universitário de Vila Velha, Vila Velha, ES, Brazil. levy.gomes@uvv.br

${ }^{4}$ Embrapa Amazônia Ocidental, Manaus, AM, Brazil. edsandra@cpaa.embrapa.br

${ }^{5}$ Florida International University, Miami, FL, USA. rpbrinn@yahoo.com

'Instituto Nacional de Pesquisas da Amazônia, Manaus, AM, Brazil. roubach@inpa.gov.br 


\section{Introduction}

Tributaries in the Amazon basin exhibit a range of different chemical characteristics. They were classified into three major types on the basis of their appearance as "white waters", “clear waters” and “black waters” (Gibbs, 1972). Two major rivers the Solimões River and the Negro River join at Manaus to form the Amazon River. The white water (brownish in reality) of the Solimões River has a high amount of suspended sediments (Tardy et al., 2005), neutral pH and is comparatively rich in ions (Aucour et al., 2003). The Negro River is called "black water river", with much lower ion concentrations (5-20 fold lower than white water), pH of 5.0-6.0 and greater amounts of dissolved organic matter (Aucour et al., 2003; Mortatti \& Probst, 2003). In small streams or flooded forests of the Negro River basin the high concentrations of humic and fulvic acids formed in the soil through the decomposition of organic matter can reduce water $\mathrm{pH}$ down to 3.0-4.0 (Küchler et al., 2000; Matsuo \& Val 2003). Clear water is found in few rivers like the Tapajós River and has two fold higher $\mathrm{Ca}^{2+}$ concentrations than black waters and neutral pH (Konhauser et al., 1994).

Normally the floodplain Amazon lakes are supplied by waters from small acidic black water streams year round and by the white waters of the Amazon River during the rainy season. Therefore several Amazon fishes are exposed to seasonal changes from white to black waters and vice-versa year around in the lakes (Araújo-Lima \& Goulding, 1997; Barthem \& Goulding, 1997) and a few even enter the acidic black waters of the small streams or flooded forests or migrate between those different types of water (Araújo-Lima \& Goulding, 1997).

Several studies of ion fluxes between the fishes and their external media were performed in samples collected from the Negro River (Gonzalez et al. 1997, 1998, 2002; Wood et al., 1998; Wilson et al., 1999; Gonzalez \& Wilson, 2001) and some demonstrated that they are more resistant to acidic waters than those that do not live in black waters (Wilson et al., 1999; Gonzalez et al. 1997, 2002). However, only two studies analyzed $\mathrm{Ca}^{2+}$ fluxes in Amazon fishes, and they were performed with modified well water, which is similar to the “clear water” (Wilson et al., 1999; Matsuo et al., 2005). In addition, transfer of tamoatá (Hoplosternum littorale) and pirarucus (Arapaima gigas) from black water to white water or vice-versa induced only minor changes on net $\mathrm{Na}^{+}, \mathrm{K}^{+}$and $\mathrm{Cl}^{-}$fluxes (Baldisserotto et al., 2008), but $\mathrm{Ca}^{2+}$ fluxes were not studied. In addition, waterborne $\mathrm{Ca}^{2+}$ uptake occurs much slower than $\mathrm{Na}^{+}$uptake (Matsuo et al., 2005). Calcium is essential to fish for several biological processes such as bone construction, blood coagulation, and many other cellular functions (Flik et al., 1995). Plasma $\mathrm{Ca}^{2+}$ is regulated by food sources or by branchial absorption (Flik \& Verbost, 1995). In teleost fish in general $99 \%$ of the internal sources of $\mathrm{Ca}^{2+}$ are incorporated into bone, scales, teeth and otoliths, and the readily exchangeable $\mathrm{Ca}^{2+}$ in the bone of Mozambique tilapia (Oreochromis mossambicus) maintained at $200 \mu \mathrm{mol} . \mathrm{L}^{-1} \mathrm{Ca}^{2+}$ (concentration similar to white water) is around 19\% (Flik et al., 1986). The same authors also verified that waterborne $\mathrm{Ca}^{2+}$ levels influenced $\mathrm{Ca}^{2+}$ fluxes in this species. Therefore, the aim of the present study was to analyze net $\mathrm{Ca}^{2+}$ fluxes in tamoatá exposed to different types of Amazonian waters.

\section{Material and Methods}

Experimental animals and management conditions. Tamoatá juveniles (9-26 g) were raised in a 200- $\mathrm{m}^{3}$ earth pond at the Embrapa fish culture sector (Manaus, Amazonas, Brazil). One month before the experiments fish were transferred to a 2000 $\mathrm{L}$ indoor fiberglass tank and fed three times a day with a commercial pelleted feed with 45\% crude protein (TR 45; Nutron, São Paulo, Brazil). The earth pond at Embrapa and the indoor tank were supplied with well water $\left(26-27^{\circ} \mathrm{C}\right)\left(\mu \mathrm{mol} . \mathrm{L}^{-1}\right)$ : [Na] 48.6, [K] - 39.6, [Ca] - 32.0, [Cl] - 55.2, $\mathrm{pH}=5.5$.

$\mathrm{Ca}^{2+}$ flux measurements. After acclimation to these pond conditions, randomly selected fish were placed in individual chambers $(420 \mathrm{~mL})$ containing one of three water chemistries; i) black water ( $\mu \mathrm{mol} / \mathrm{L})$ : [Na] - 24.7, [K] - 12.2, [Ca] - 26.6, [Cl] 29.0, $\mathrm{pH}=5.7$, ii) black water adjusted to $\mathrm{pH} 3.5$ with $0.5 \mathrm{M}$ $\mathrm{H}_{2} \mathrm{SO}_{4}$, or iii) white water ( $\left.\mu \mathrm{mol} / \mathrm{L}\right)$ : $[\mathrm{Na}]-135.4$, [K] - 25.8, [Ca] - 248.5, [Cl] - 116.8, $\mathrm{pH}=7.0$. Black water was collected in the Negro River and white water in the Solimões River, both places near Manaus. Dissolved organic matter is 15.5 mg. $\mathrm{L}^{-1}$ in both black water and acidic black water (Gonzalez et al., 2002) and $2.0 \mathrm{mg} . \mathrm{L}^{-1}$ in well water and white water (Wood et al., 1998). This first exposure lasted four hours, and then the water in the chambers was replaced by a different type of water and the fish remained in the chamber for an additional $4 \mathrm{~h}$ (second exposure). The different water combinations used are listed in Table 1. The control group was submitted to the same handling procedure, but remained in well water for the $8 \mathrm{~h}$ experimental period. Water temperature, $\mathrm{pH}$ (using a $\mathrm{pH} 100$, YSI Inc., Yellow Springs, OH, USA) and dissolved oxygen levels (using a YSI DO200 oxygen meter) were measured. Water $\mathrm{pH}$ in the chambers was adjusted only at the beginning of each exposure and measured at the beginning and the end of the second exposure $(4 \mathrm{~h})$ to the different waters, and mean maximum differential between initial and final $\mathrm{pH}$ readings were $0.17,0.18,-0.35$ and 0.75 units in the black water and acidic black water, white water and well water, respectively.

Table 1. Different types of Amazonian waters where Hoplosternum littorale was exposed for determination of ion fluxes. There were two successive measurement periods of $2 \mathrm{~h}$ in each exposure. $\mathrm{N}=10$ for each treatment.

\begin{tabular}{ll}
\hline \multicolumn{1}{c}{ First exposure $(4 \mathrm{~h})$} & \multicolumn{1}{c}{ Second exposure $(4 \mathrm{~h})$} \\
\hline black water pH 5.7 & white water pH 7.0 \\
black water pH 5.7 & black water pH 3.5 \\
black water pH 3.5 & black water pH 5.7 \\
black water pH 3.5 & white water pH 7.0 \\
white water pH 7.0 & black water pH 5.7 \\
white water pH 7.0 & black water pH 3.5 \\
well water pH 5.5 & well water pH 5.5 \\
\hline
\end{tabular}


Water temperature in the chambers was $25-27^{\circ} \mathrm{C}$ and dissolved oxygen levels 4-7 $\mathrm{mg} \mathrm{L}^{-1}$. Water samples $(10 \mathrm{~mL})$ were taken from the chambers at the beginning and every $2 \mathrm{~h}$ up to the end of the experiment and stored in the $-20^{\circ} \mathrm{C}$ freezer for analysis of $\mathrm{Ca}^{2+}$ concentrations. The fish were weighed at the end of the experiment.

Water $\mathrm{Ca}^{2+}$ levels were measured directly with an AA-1475 atomic absorption spectrophotometer (AAS 11 VARIAN, Australia, $\mathrm{Ca}^{2+}$ sensitivity $3.0 \mu \mathrm{mol} . \mathrm{L}^{-1}$ ) after addition of a concentrated solution of lanthanum chloride (yielding a solution of $0.2 \%$ lanthanum chloride) to reduce interferences in the measurement. Net $\mathrm{Ca}^{2+}$ fluxes were calculated according to Gonzalez et al. (1998) Jnet $=\mathrm{V}\left([\mathrm{ion}]_{1}-[\mathrm{ion}]_{2}\right) \cdot(\mathrm{Mt})^{-1}$. Where $[i o n]_{1}$ and [ion $]_{2}$ are the bath ion concentrations at the beginning and end of the flux period (every two hours), respectively, $\mathrm{V}$ is the bath volume (in liters), $\mathrm{M}$ is the mass of the fish (in $\mathrm{kg}$ ), and $t$ is the duration of the flux period (in hours).

Statistical analysis. Homogeneity of variances was verified by the Levene test. Variances were not homocedastic and therefore net ion fluxes and water $\mathrm{pH}$ changes due to different treatments and times were compared using the Kruskall-Wallis ANOVA and Mann-Whitney tests, with the aid of the software Statistica 5.1. Data were expressed as mean \pm SEM, and the minimum significance level was $\mathrm{P}<0.05$.

\section{Results}

First exposure. Tamoatás transferred from the tanks of ionpoor well water to flux chambers containing ion-poor acidic black water showed significantly greater $\mathrm{Ca}^{2+}$ loss than those transferred to the other waters during the first two hours of exposure. Fish transferred from ion-poor black water and those maintained in well water presented low net $\mathrm{Ca}^{2+}$ efflux, while those transferred to white water showed net $\mathrm{Ca}^{2+}$ influx. Through the 2-4 h period after transfer from the tanks, net $\mathrm{Ca}^{2+}$ efflux of tamoatás maintained in acidic black water reduced to zero and those kept in black water and well water presented low net influx (Figs. 1 and 2), whereas fish in white water increased their net $\mathrm{Ca}^{2+}$ influxes by more than three-fold (Fig. 2).

Second exposure. Specimens maintained in well water in the first exposure and with renewal of this well water in the second exposure did not show any significant change in net $\mathrm{Ca}^{2+}$ flux up to end of the experiment (Fig. 1). Transfer of tamoatás from black water to acidic black water led to net $\mathrm{Ca}^{2+}$ efflux in the first $2 \mathrm{~h}$, but as in the first exposure, at the end of $4 \mathrm{~h}$ reversed to a $\mathrm{Ca}^{2+}$ influx (Fig. 3a). On the other hand, fish transferred from acidic black water to black water did not show any significant change in net $\mathrm{Ca}^{2+}$ fluxes in the first $2 \mathrm{~h}$, but in the 2-4 h period there was a net $\mathrm{Ca}^{2+}$ influx (Fig. 3b). Tamoatás transferred to white water irrespective of previous exposure (black water or acidic black water), presented a significant increase of the net $\mathrm{Ca}^{2+}$ influxes compared to the fluxes in the previous water type, which then remained constant through the $4 \mathrm{~h}$ of the second exposure (Fig. 3a-b). Transfer from white water to black water or acidic black water led to net $\mathrm{Ca}^{2+}$ effluxes in the first $2 \mathrm{~h}$ of exposure, and which were reversed to net influx (black water) or reduced to zero (acidic black water) during the 2-4 $\mathrm{h}$ period (Fig. 3c).

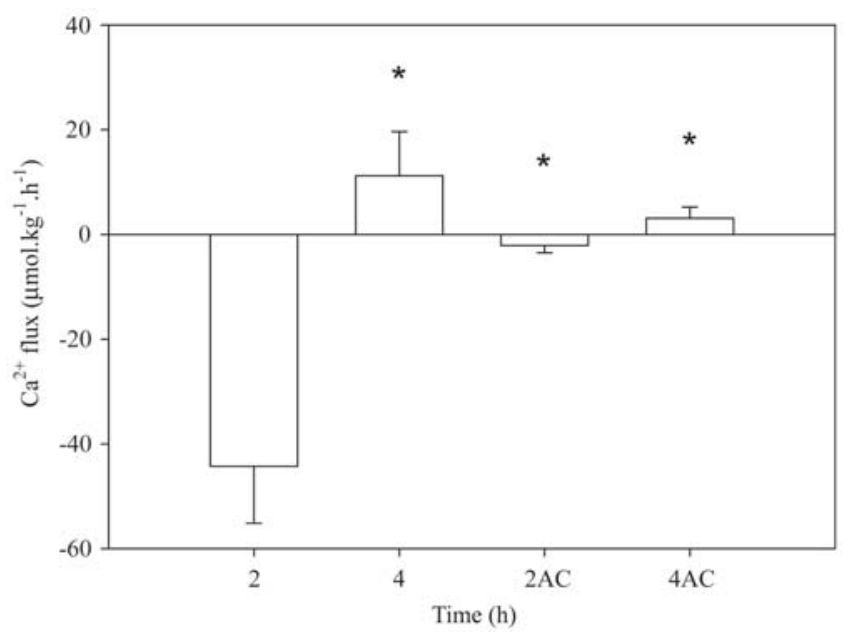

Fig. 1. Net $\mathrm{Ca}^{2+}$ fluxes of Hoplosternum littorale exposed to well water as a function of time after transfer from tanks of ion-poor well water. Data expressed as mean \pm SEM. Positive values indicate net influxes and negative values net effluxes. AC - after change. Asterisks (*) indicate significantly different from $2 \mathrm{~h}$ by Kruskall-Wallis ANOVA and Mann-Whitney test $(\mathrm{P}<0.05)$.

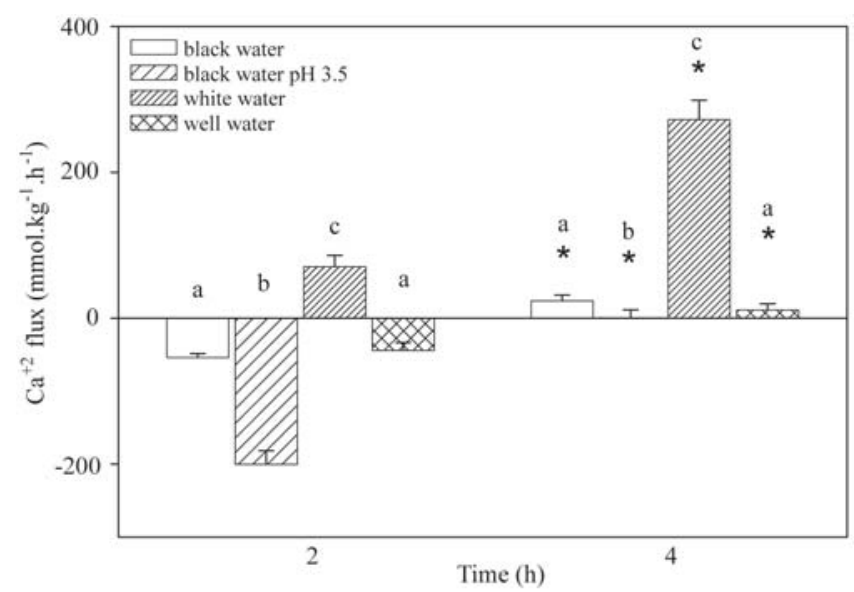

Fig. 2. Net $\mathrm{Ca}^{2+}$ fluxes of Hoplosternum littorale transferred from tanks of ion-poor well water to experimental flux chambers containing different Amazonian waters. The first four bars show fluxes measured over the first 2 hours, and the second set of four bars show data for the 2-4 h period after initial transfer. Data expressed as mean \pm SEM. Positive values indicate net influxes and negative values net effluxes. Different letters indicate significant differences among groups in the same period of time by Kruskall-Wallis ANOVA and MannWhitney test $(\mathrm{P}<0.05)$. Asteriks $(*)$ indicate significantly different from the same group at $2 \mathrm{~h}(\mathrm{P}<0.05)$ 

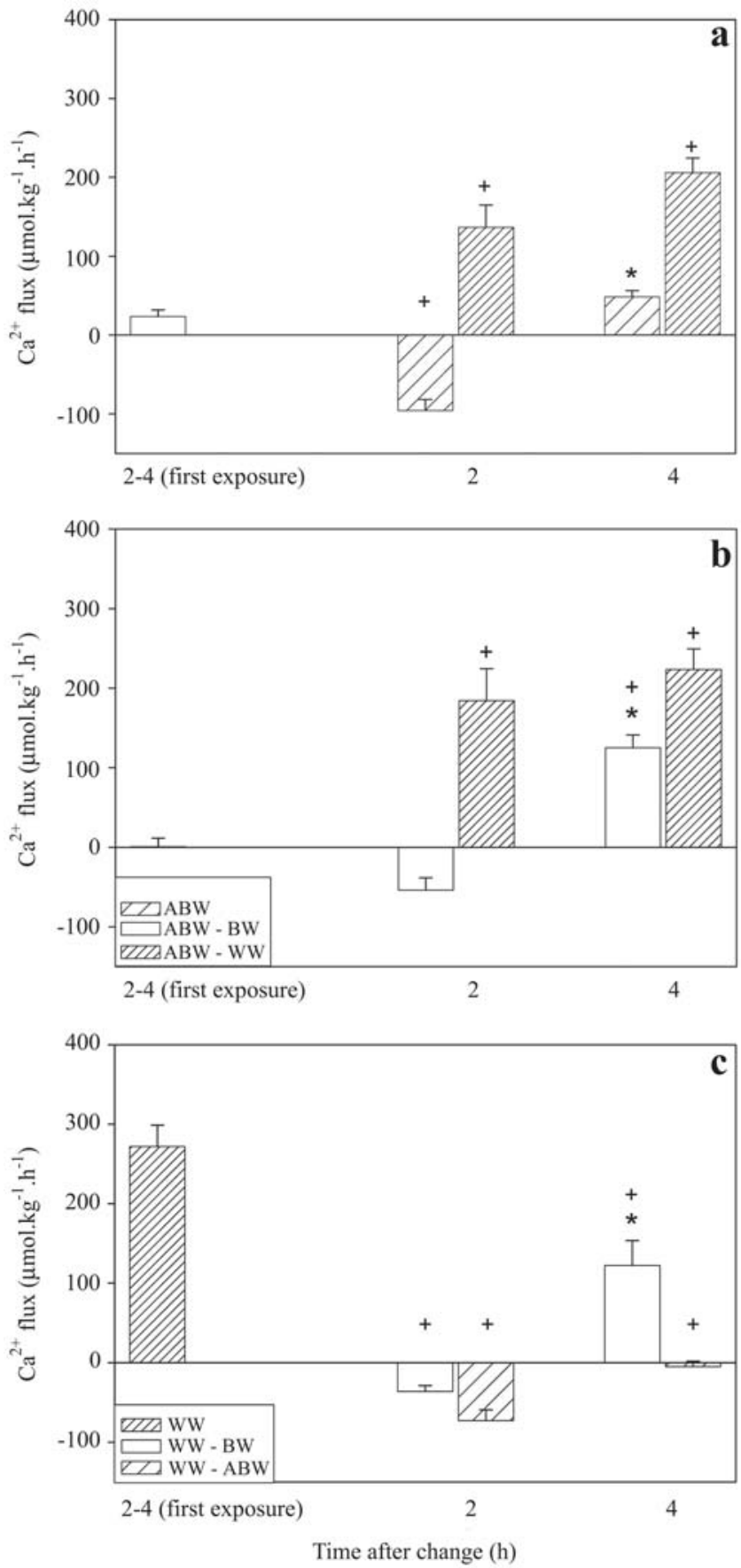

Fig. 3. Net $\mathrm{Ca}^{2+}$ fluxes of Hoplosternum littorale transferred from black water (BW) to acidic black water pH 3.5 (ABW) or white water (WW) (a), and fish transferred from ABW to BW or WW (b) and fish transferred from WW to BW or ABW (c). The first bar in the left side of the figure represents the 2-4 $\mathrm{h}$ flux of the first exposure. Data expressed as mean \pm SEM. Positive values indicate net influxes and negative values net effluxes. Asterisks (*) indicate significantly different from the same group $2 \mathrm{~h}$ after transfer by KruskallWallis ANOVA and Mann-Whitney test $(\mathrm{P}<0.05)$. Crosses $(+)$ indicate significantly different from the previous water condition by Kruskall-Wallis ANOVA and Mann-Whitney test $(\mathrm{P}<0.05)$.

\section{Discussion}

The mitochondria-rich cells, located in the gill epithelia, are probably the most important site for $\mathrm{Ca}^{2+}$ uptake in fish. The intracellular $\mathrm{Ca}^{2+}$ concentration of the chloride cells is very low, and consequently apical uptake is diffusional by a $\mathrm{Ca}^{2+}$ channel even from soft water (Evans et al., 2005). The exit of $\mathrm{Ca}^{2+}$ across the basolateral membrane is active, involving the $\mathrm{Ca}^{2+}$-ATPase and the $\mathrm{Na}^{+} / \mathrm{Ca}^{2+}$ exchanger (Guerreiro \& Fuentes, 2007). Tamoatás transferred to chambers with ion-poor black water or well water presented net $\mathrm{Ca}^{2+}$ efflux in the first $2 \mathrm{~h}$ of experiment. This was expected because tamoatás had not been given time to recover from any handling stress after transfer to the chambers, which is very likely to result in net ion loss (Postlethwaite \& McDonald, 1995). Stress increases gill blood flow and paracellular permeability, resulting in ion loss (Cech et al., 1996). Recovery is variable depending on the intensity of stress and species (Gonzalez \& McDonald, 1994; Baldisserotto \& Val, 2002; Rosso et al., 2006). In the present experiment apparently stress was reduced after $2 \mathrm{~h}$, since net $\mathrm{Ca}^{2+}$ fluxes in tamoatás in black water and well water became net influxes, and values were similar to those determined by Wilson et al. (1999) for the same species and Brycon erythropterum (= Brycon cephalus) exposed to well water at $\mathrm{pH}$ 6.0. $\mathrm{Net}^{2+}$ loss was significantly higher in tamoatá exposed to acidic black water, which was also expected because this water induces net $\mathrm{Na}^{+}$, $\mathrm{Cl}^{-}$and $\mathrm{K}^{+}$effluxes in this species (Baldisserotto et al., 2008). Tamoatá transferred to ion-rich white water led to net $\mathrm{Ca}^{2+}$ influxes, which increased after $2 \mathrm{~h}$. Apparently the approximately 10 -fold higher $\mathrm{Ca}^{2+}$ concentration in white water (compared to both black water and well water) was enough to avoid net $\mathrm{Ca}^{2+}$ loss or increased $\mathrm{Ca}^{2+}$ influx. In disagreement with these results, Mozambique tilapia acclimated to water with $200 \mu \mathrm{mol} . \mathrm{L}^{-1} \mathrm{Ca}^{2+}$ presented higher net $\mathrm{Ca}^{2+}$ influx compared to those adapted to $800 \mu \mathrm{mol} . \mathrm{L}^{-1} \mathrm{Ca}^{2+}$ (Flik et al., 1986). Probably this difference is due to the fact that in the study of Flik et al. (1986) $\mathrm{Ca}^{2+}$ fluxes were determined after 10 weeks acclimation, which may allow for increased chloride cell proliferation, and in the present study fluxes were measured 2-4 h after transference. Small changes of waterborne $\mathrm{Ca}^{2+}$ are easier to detect by AAS in ion-poor black and well water, but usually more difficult in white water, which contains comparatively higher $\mathrm{Ca}^{2+}$ levels. However, net $\mathrm{Ca}^{2+}$ fluxes in tamoatá acclimated to white water were high enough to allow measurements with satisfactory precision. Additional experiments with tamoatá acclimated to white water for a longer period of time and with radioactive isotopes must be performed.

Transfer of tamoatás from ion-poor black water and acidic black water or ion-rich white water to ion-poor black water or acidic black water resulted in net $\mathrm{Ca}^{2+}$ loss only in the first $2 \mathrm{~h}$ of experiment. The same kind of transfers in tamoatás led to net $\mathrm{Na}^{+}, \mathrm{Cl}^{-}$and $\mathrm{K}^{+}$loss through $4 \mathrm{~h}$ (except $\mathrm{Cl}^{-}$and $\mathrm{K}^{+}$in tamotás transferred from white water to black water) (Baldisserotto et al., 2008). Net $\mathrm{Na}^{+}, \mathrm{Cl}^{-}$and $\mathrm{K}^{+}$losses after 
transfer from black water ( $\mathrm{pH}$ 5.5) or slightly acid well water (pH 6.5) to acidic black water ( $\mathrm{pH}$ 3.5-3.75) were also observed by Gonzalez et al. (1998), Wood et al. (1998) and Wilson et al. (1999) in tambaqui (Colossoma macropomum) and by (Gonzalez et al., 2002) in Geophagus sp. and Pimelodus sp. caught in the Negro River. Exposure to very acidic water loosens tight junctions of gill epithelia, which increases ion efflux by a paracellular route (Wood, 2001). However, unlike the patterns for the monovalent ions, there was no obvious trend for net $\mathrm{Ca}^{2+}$ fluxes in tamoatá, tambaqui and matrinxã [Brycon erythropterum (= B. cephalus)] exposed to gradual well water acidification (Wilson et al., 1999).

It seems that adjustment of $\mathrm{Ca}^{2+}$ fluxes to these changes in Amazonian waters is faster than the fluxes of other ions in this species. In addition to this hypothesis, tamoatá transferred to ion-poor black water or acidic black water to ion rich white water presented net only net $\mathrm{Ca}^{2+}$ influxes, while according to Baldisserotto et al. (2008) there was net $\mathrm{Na}^{+}$loss at least in the first $2 \mathrm{~h}$ after these transfers.

The results obtained allowed us to conclude that transfer of tamoatá from ion-poor waters (black water and acidic black water) led to transient net $\mathrm{Ca}^{2+}$ loss, while the amount of $\mathrm{Ca}^{2+}$ in the ion-rich white water seems adequate to prevent $\mathrm{Ca}^{2+}$ loss after transfer. Therefore, transfer of tamoatá between these Amazonian waters does not seem to result in serious $\mathrm{Ca}^{2+}$ disturbance.

\section{Acknowledgements}

This study was supported by CNPq grants \# 475093/20038 and \# 506943/2004-6. B. Baldisserotto, L. C. Gomes and R. Roubach are fellowship researchers from CNPq.

\section{Literature Cited}

Araújo-Lima, C. A. R. M. \& M. Goulding. 1997. So fruitful a fish. Ecology, conservation and aquaculture of the Amazon's tambaqui. New York, Columbia University, 214p.

Aucour, A. M., F. A. Tao, P. Moreira-Turcq, P. Seyler, S. Sheppard \& M. F. Benedetti. 2003. The Amazon River: behaviour of metals (Fe, $\mathrm{Al}, \mathrm{Mn}$ ) and dissolved organic matter in the initial mixing at the Rio Negro/Solimões confluence. Chemical Geology, 197: 271-285.

Baldisserotto, B., C. E. Copatti, L. C. Gomes, E. C. Chagas, R. P. Brinn \& R. Roubach. 2008. Net ion fluxes in the facultative air-breather Hoplosternum littorale (tamoata) and the obligate air-breather Arapaima gigas (pirarucu) exposed to different Amazonian waters. Fish Physiology and Biochemistry, 34(4): 405-412.

Baldisserotto, B. \& A. L. Val. 2002. Ion fluxes of Metynnis hypsauchen, a teleost from the Rio Negro, Amazon, exposed to an increase of temperature. Brazilian Journal of Biology, 62: 749-752.

Cech, J. J. R., S. D. Bartholow, P. S. Young \& T. E. Hopkins. 1996. Striped bass exercise and handling stress in freshwater: physiological responses to recovery environment. Transactions of the American Fisheries Society, 125: 308-320.

Evans, D. H., P. M. Piermarini \& K. P. Choe. 2005. The multifunctional fish gill: dominant site of gas exchange, osmoregulation, acid-base regulation, and excretion of nitrogenous waste. Physiological Reviews, 85: 97-177.
Flik, G., J. C. Fenwick, Z. Kolar, N. Mayer Gostan \& S. E. Wendelaar Bonga. 1986. Effects of low ambient calcium levels on wholebody $\mathrm{Ca}^{2+}$ flux rates and internal calcium pools in the freshwater cichlid teleost, Oreochromis mossambicus. Journal of Experimental Biology, 120: 249-264.

Flik, G. \& P. M. Verbost. 1995. Cellular mechanisms in calcium transport and homeostasis in fishes, 5. Pp. 252-263. In: Hochachka, P. W. \& T. P. Mommsen (Eds.). Biochemistry and Molecular Biology of Fishes. Amsterdam, Elsevier, 468p.

Flik, G., P. M. Verbost \& S. E. Wendelaar Bonga. 1995. Calcium transport processes in fishes. Pp. 317-341. In: Wood, C. M. \& T. J. Shuttleworth (Eds.). Cellular and Molecular Approaches to Fish Ionic Regulation. San Diego, Academic Press, 350p.

Gibbs, R. J. 1972. Water chemistry of the Amazon River. Geochimica et Cosmochimica Acta, 36: 1061-1066.

Gonzalez, R. J., V. M. Dalton \& M. L. Patrick. 1997. Ion regulation in ion-poor acidic water by the blackskirt tetra (Gymnocorymbus ternetzi), a fish native to the Amazon River. Physiological and Biochemical Zoology, 70: 428-435.

Gonzalez, R. J. \& D. G. McDonald. 1994. The relationship between oxygen uptake and ion loss in fish from diverse habitats. Journal of Experimental Biology, 190: 95-108.

Gonzalez, R. J. \& R. W. Wilson. 2001. Patterns of ion regulation in acidophilic fish native to the ion-poor, acidic Rio Negro. Journal of Fish Biology, 58: 1680-1690.

Gonzalez, R. J., R. W. Wilson, C. M. Wood, M. L. Patrick \& A. L. Val. 2002. Diverse strategies for ion regulation in fish collected from the ion-poor, acidic Rio Negro. Physiological and Biochemical Zoology, 75: 37-47.

Gonzalez, R. J., C. M. Wood, R. W. Wilson, M. L. Patrick, H. L. Bergman, A. Narahara \& A. L. Val. 1998. Effects of water $\mathrm{pH}$ and calcium concentration on ion balance in fish of the Rio Negro, Amazon. Physiological and Biochemical Zoology, 71: 15-22.

Guerreiro, P. M. \& J. Fuentes. 2007. Control of calcium balance in fish. Pp. 427-495. In: Baldisserotto, B., J. M. Mancera \& B. G. Kapoor (Eds.). Fish Osmoregulation. Enfield, Science Publishers, 527p.

Konhauser, K. O., W. S. Fyfe \& B. I. Kronberg. 1994. Multielement chemistry of some Amazonian water and soils. Chemical Geology, 111: 155-175.

Küchler, I. L., N. Miekeley \& B. R. Forsberg. 2000. A contribution to the chemical characterization of rivers in the Rio Negro Basin, Brazil. Journal of the Brazilian Chemical Society, 11: 286-292.

Matsuo A. Y. O. \& A. L.Val. 2003 Fish adaptations to Amazonian blackwaters. Pp. 1-36. In: Val, A. L. \& B. G. Kapoor (Eds.). Fish adaptations. Enfield, Science Publishers, 432p.

Matsuo, A.Y., C. M. Wood \& A. L. Val. 2005. Effects of copper and cadmium on ion transport and gill metal binding in the Amazonian teleost tambaqui (Colossoma macropomum) in extremely soft water. Aquatic Toxicology, 74: 351-364.

Mortatti, J. \& J. L. Probst. 2003. Silicate rock weathering and atmospheric/soil $\mathrm{CO}_{2}$ uptake in the Amazon basin estimated from river water geochemistry: seasonal and spatial variations. Chemical Geology, 197: 177-196.

Postlethwaite, E. K. \& D. G. McDonald. 1995. Mechanisms of $\mathrm{Na}^{+}$ and $\mathrm{Cl}^{-}$regulation in freshwater-adapted rainbow trout (Oncorhynchus mykiss) during exercise and stress. Journal of Experimental Biology, 198: 295-304.

Rosso, F. L., K. C. S. Bolner \& B. Baldisserotto. 2006. Ion fluxes in silver catfish (Rhamdia quelen) juveniles exposed to different dissolved oxygen levels. Neotropical Ichthyology, 4(4): 435440. 
Tardy, Y., V. Bustillo, C. Roquin, J. Mortatti \& R. Victoria. 2005. The Amazon. Bio-geochemistry applied to river basin management Part I. Hydro-climatology, hydrograph separation, mass transfer balances, stable isotopes, and modeling. Applied Geochemistry, 20: 1746-1829.

Wilson, R. W., C. M. Wood, R. J. Gonzalez, M. L. Patrick, H. L. Bergman, A. Narahara \& A. L. Val. 1999. Ion and acid-base balance in three species of Amazonian fish during gradual acidification of extremely soft water. Physiological and Biochemical Zoology, 72: 277-285.

Wood, C. M. 2001. Toxic response of the gill. Pp. 1-89. In: Schlenk, D. \& W. H. Benson (Eds.). Target Organ Toxicity in Marine and Freshwater Teleosts. London, Taylor \& Francis, 372p.

Wood, C. M., R. W. Wilson, R. J. Gonzalez, M. L. Patrick, H. L. Bergman, A. Narahara \& A. L. Val. 1998. Responses of an Amazonian teleost, the tambaqui (Colossoma macropomum), to low $\mathrm{pH}$ in extremely soft water. Physiological and Biochemical Zoology, 71: 658-670.

Accepted June 18, 2009

Published September 30, 2009 